\title{
ПРОБЛЕМНОЕ ОБУЧЕНИЕ КАК СРЕДСТВО ФОРМИРОВАНИЯ ТВОРЧЕСКОГО МЬШЛЕНИЯ БУДУЩЕГО УЧИТЕЛЯ ФИЗИЧЕСКОЙ КУЛЬТУРЫ
}

\section{PROBLEM LEARNING AS A MEANS OF SHAPING THE CREATIVE THINKING OF A FUTURE PHYSICAL EDUCATION TEACHER}

\section{O. Omarov}

B. Borlakova

N. Novikova

Summary: Experience of organization of education in higher pedagogical educational institution in system of teaching of disciplines of sports and pedagogical cycle is considered. It is shown that the effectiveness of the formation of professional competencies is achieved in the conditions of problematic training, based on the specifics of the professional activity of a teacher in physical culture and sports in the context of solving multilevel problem tasks.

Keywords: professional activity of the teacher, problem training, design and didactic tasks.
Омаров Омаркады Магомедзагирович К.п.н., дочент, ФГБОУ ВО «Дагестанский государственный педагогический университет» (2. Махачкала), omar-kadi@yandex.ru

Борлакова Баблина Магомедовна К.п.н., дочент, ФГБОУ ВО «Карачаево-Черкесский государственный университет» (2. Карачаевск), bablina.borlakova@yandex.ru

Новикова Наталья Борисовна

Доцент, ФГБОУ ВО «Дагестанский государственный университет» (2. Махачкала) omar-kadi@yandex.ru

Аннотация: Рассматривается опыт организации обучения в высшем педагогическом учебном заведении в системе преподавания дисциплин спортивно-педагогического цикла. Показано, что эффективность формирования профессиональных компетенций достигается в условиях проблемного обучения, основанного на специфике профессиональной деятельности педагога по физической культуре и спорту в контексте решения разноуровневых проблемных заданий.

Ключевые слова: профессиональная деятельность педагога, проблемное обучение, проектировочно-дидактические задания.

Важность осуществления ведущих профессионально-педагогических умений и навыков педагога, в частности, учителя физической культуры обусловливает необходимость их качественного формирования в процессе обучения в вузе. Основными критериями качества освоенных знаний выпускниками физкультурных факультетов являются успешность их применения при решении возникших профессиональных проблем на основе выявления сути основных структурных связей в проектируемом учебном процессе и прогнозирования результатов профессиональной деятельности. Владение умениями и навыками принимать нестандартные педагогические решения - импровизировать и быть гибким в профессиональных ситуациях вариантности (выбора оптимальных путей разрешения возникающих учебных проблем и готовности к преодолению возникающих трудностей); целенаправленно выбирать применяемые формы, методы и средства обучения по назначению $[2-6,8,11]$.

Становление педагога нового типа - сложный и многоэтапный процесс. При этом, качество подготовки современных специалистов по физической культуре и спорту во многом определяется эффективностью преподавания профилирующих дисциплин - гимнастика, 
легкая атлетика, волейбол, баскетбол и т.д., в учебном процессе которых собственно и устанавливается «связь теории и практики» при выполнении практических заданий с использованием средств данной спортивной дисциплины.

Однако консервативный характер сложившейся системы физкультурно-педагогического образования, в рамках преподавания профилирующих дисциплин спортивно-педагогического цикла, вызывает определенные трудности в реализации компетентностного подхода к подготовке будущего педагога. В частности, практическая подготовка выпускников факультетов физической культуры признается рядом современных исследователей как одно из слабых звеньев в системе отечественного высшего физкультурного образования. В первую очередь по причине ее оторванности от профессиональной деятельности, разрыва между теоретическими и методическими знаниями студента с одной стороны, и умениями целенаправленно применять их при решении различных педагогических задач, проблемных учебных ситуаций $[1,7,9,13]$.

Данная проблема, по-нашему мнению, связана с неадекватностью традиционных форм и методов преподавания, используемых в системе дисциплин спортивно-педагогического цикла (гимнастика, легкая атлетика, баскетбол и т.д.) и качества проведения учебной (педагогической) практики задачам подготовки современного педагога к профессиональной деятельности. Это означает, что целевые ориентиры образовательного процесса должны быть в большей степени направлены на формирование проектно-технологической компетентности будущего педагога ФК, способного самостоятельно ставить профессиональные задачи и эффективно решать их в достижении учебных целей $[6,8]$.

Вследствие вышесказанного в образовательном процессе спортивно-педагогических дисциплин назрела необходимость обновления содержания и организации учебного процесса, применения новых технологий, способствующих совершенствованию, корректировке, дифференциации содержания обучения, применения системного подхода в обучении студентов. Важная роль в системе спортивно-педагогических дисциплин отводится предмету «Гимнастика», являющегося базовым учебным предметом в профессиональной подготовке будущих учителей физической культуры, который в своей структуре включает значительный арсенал средств обучения - разнообразных физических упражнений.

Широкий спектр образовательных задач, которые можно решать с помощью гимнастических упражнений определяется их многоструктурностью и многофункциональностью. Эти свойства открывают широкие возможности для подбора средств обучения - физических упражнений и способов их использования в обучающих, воспитательных, оздоровительно-прикладных целях. В практике профессиональной подготовки физкультурных кадров гимнастические упражнения должны рассматриваться не как «набор отдельных гимнастических элементов», а как система средств обучения (имеющие сложную биомеханическую и ритмическую структуры), применяемых студентами во всех компонентах учебной и профессиональной деятельности, в которой они совершенствуются:

- в спортивной деятельности - использование арсенала гимнастических упражнений в качестве подготовительных к тренировочной и соревновательной деятельности;

- в учебной деятельности - освоение техники гимнастических упражнений на практических занятиях, с параллельной отработкой вопросов дидактического взаимодействия учителя и учащихся (сочетание освоения двигательных действий с освоением методики обучения этим двигательным действиям), формирование профессиональной культуры речи (овладение гимнастической терминологией); анализ различных конкретных учебных ситуаций, связанных с будущей профессиональной деятельностью;

- в профессиональной деятельности (в период прохождения педагогической практики в школе) проведение уроков по дисциплине «Физическая культура», тренерская работа в школьной спортивной секции, где в большей степени актуализируется профессиональная подготовка студента и проявляется с позиций сформированности проективно-технологических умений самостоятельно разрабатывать и проводить уроки физической культуры (учебно-тренировочные занятия) с детьми школьного возраста, в соответствии с задачами и содержанием обучения.

Структура дидактического процесса по обучению спортивным двигательным действиям, где на первый план выдвигается задача создание управляемого учебного процесса, включает в себя ряд последовательных этапов, в соответствии с которыми мы выделяем отдельные проектировочно-дидактические действия. В частности, для успешного обучения двигательным действиям, будущий учитель физической культуры должен овладеть следующими умениями:

1. Аналитические умения: педагог владеет умением ориентироваться в различных сложившихся педагогических ситуациях.

2. Прогностические умения: педагог владеет умениями проектировать ход развития дидактического процесса (в конкретных проектируемых педагогических ситуациях), соотнося его с различными вариантами педагогических воздействий на учащихся. 
3. Умения целеполагания: педагог владеет технологией целеполагания - умеет самостоятельно определять и формулировать обучающие цели, основываясь на результатах анализа и прогноза дидактического процесса.

4. Проектно-конструктивные умения: педагог владеет проективно-конструктивными умениями (исходя из поставленной цели обучения) планировать учебно-познавательную деятельность, т.е. определять частные задачи и процессуально-технологическую последовательность их реализации с учетом содержания и имеющихся средств, и методов обучения.

5. Управленческие умения: педагог владеет умениями реализовывать проект учебного процесса в условиях реального дидактического процесса.

6. Контролирующие умения: педагог владеет умениями текущего и промежуточного контроля учебной деятельности обучающихся по ходу продвижения к цели обучения.

7. Корректировочные умения: педагог владеет умениями корректировать ход решения обучающей задачи, соотнося реальные промежуточные и конечные результаты учебного процесса с запланированными (проектируемыми).

Таким образом преподавателю необходимо уметь создать педагогические условия, когда профессиональная подготовка студента проявляется во всех компонентах управляемого дидактического процесса по овладению техникой гимнастических упражнений, в процессе которого повышается эффективность освоения профессионально-предметных знаний, формируются творческое и профессиональное мышление, методические и проективно-технологические умения обучать школьников данным упражнениям с последующим их применением в процессе самостоятельных занятий физической культурой и спортом.

В современных условиях образовательного процесса в педагогическом вузе основным конкурентным ресурсом, обеспечивающего личностное развитие студента, выход за пределы нормативной профессиональной деятельности, является способность самостоятельной организации учебной деятельности [12]. Соответственно, важным компонентом в профессиональной подготовке будущего учителя физической культуры мы видим в необходимости формирования умений самостоятельно приобретать и углублять свои профессиональные знания, а также стойкие познавательные мотивы и дидактические умения - практически оперировать освоенными дидактическими технологиями, операциональными процедурами на отдельных этапах дидактического процесса, выступающими в качестве средства решения профессиональных задач в вариативных условиях конкретных учебных ситуаций.
Решение данных задач на практических занятиях по дисциплине «Гимнастика» (бакалавры направления подготовки 44.03.01 Педагогическое образование, профиль «Физическая культура» и 44.03.05 Педагогическое образование, профили «Физическая культура» и «Дополнительное образование (спортивная подготовка)» в ФГБОУ ВО «ДГПУ» осуществляется в рамках обоснования разнообразных подходов к построению и совершенствованию учебного процесса: его организации, распределению программного материала и времени на освоение его разделов, использованию различных вариантов содержания учебных занятий, дидактических форм, средств и методов (методы преподавания и методы учения). В частности, с целью формирования готовности к инновационной деятельности (моделирование учебного процесса и педагогических ситуаций по предмету «Физическая культура», разработка и обоснование средств, методов и критериев оценивания образовательных достижений учащихся) в условиях общеобразовательной школы, центральным звеном в учебном процессе отводится методам проблемного обучения, которые позволяют нам приобщать студентов к творческой деятельности в обучении спортивным двигательным действиям, тем самым активизировать их учебно-познавательную деятельность.

В определении Г.К. Селевко, методы проблемного обучения это - «методы, основанные на создании проблемных ситуаций, активной познавательной деятельности учащихся, состоящей в поиске и решении сложных вопросов, требующих актуализации знаний, анализа, умения видеть за отдельными фактами явление, закон» [10, с. 63]. Таким образом, из приведенной выше дефиниции очевидно, что в качестве существенного признака проблемных методов обучения автор выделяет особенности организачии преподавателем учебно-познавательной деятельности учащихся.

Под активизацией учебно-познавательной деятельности мы рассматриваем профессиональную деятельность преподавателя, в которой акцентируется значение повышения качества дидактической культуры студента, как ориентира развития образовательной системы преподаваемых дисциплин спортивно-педагогического цикла, и которая включает в своей структуре:

- способность преподавателя воплотить в учебном процессе максимальный уровень дидактического познания студентами «педагогической действительности», создание среды сотворчества субъектов образовательного процесса - преподавателя и студентов;

- разработка и использование такого дидактического инструментария - форм, содержания, методов и средств обучения, которые способствуют повышению мотивации, самостоятельности, творческой активности студентов в усвоении знаний, 
овладению новыми способами профессиональной самореализации;

- формирование дидактической грамотности: готовности осуществлять обучающую деятельность, способности проектировать (конструировать) учебный процесс, педагогические ситуации и принимать самостоятельные результативно-целевые решения.

В основе создания условий, направленных на практическое освоение студентами различных видов педагогической деятельности, определяющие результативность по формированию профессиональных компетенций, опыта творческой деятельности в обучении спортивным двигательным действиям, заложено целенаправленное создание преподавателем проблемных ситуаций - креативной обстановки в форме системы последовательно усложняющихся профессионально-ориентированных проблемных заданий, с учетом уровня подготовленности обучаемых. В соответствии с конкретными в данный момент способами решения проблемных заданий, при котором преподавателем совместно со студентами задействуется арсенал специальных методов и форм учебно-познавательной деятельности, в личности будущих педагогов постепенно формируются черты творческой деятельности, осуществляется организованное творческое усвоение знаний, что, в свою очередь, является условием формирования интереса, потребности в творческой профессиональной деятельности.

Переходя к рассмотрению собственного опыта практики организации дидактического процесса профессионально-ориентированной направленности, применения проблемного обучения в учебном процессе на занятиях по дисциплине «Гимнастика», отметим, что это позволило нам решать двуединую задачу: активизировать познавательную деятельность студентов (учебное задание/ задача) и готовить их к организации проблемного обучения в школе (профессиональная задача).

На первом этапе преподаватель конструирует систему профессиональной подготовки студентов-физкультурников на репродуктивном уровне: дидактический процесс основан на воспроизведении студентами практических действий, уже известных и осознанных благодаря информационно-рецептивному методу.

Второй этап - овладение опытом осуществления способов деятельности через систему упражнений в аналогичной (сходной) ситуации, с целью сформировать соответствующие умения и навыки мыслительной или практической деятельности: осуществлять критический анализ учебной ситуации; рефлексивные действия по поиску способов педагогических решений; логические выводы на основе собственного практического опыта, приобретенного в процессе учебной педагогической деятельности; конструирование собственных педагогических действий.

Следующий этап предусматривает расширение и углубление полученных знаний, доля самостоятельности студентов в решении проблемных задач (ситуаций) увеличивается. Преподаватель создает проблемную задачу и чаще всего формулирует учебную проблему (не сообщает знаний в готовом виде, а ставит перед студентами проблемные дидактические задачи, побуждая искать способы и средства их решения). В дальнейшем его роль сводится к управлению и контролю за процессом решения проблемы.

При традиционной стратегии обучения, с позиций - от знания к репродуктивному воспроизведению действий (применение способов дидактической деятельности по готовому образцу) - у студентов практически не развиваются способности к педагогической импровизации, не вырабатываются навыки самостоятельного нахождения оптимальных вариантов деятельности, позволяющие активизировать их творческую активность и когнитивно-поисковые умения с целью самостоятельного решения профессиональных задач [1, 7, 9, 13]. Использование проблемного метода в контексте формирования готовности будущего учителя к обучению школьников спортивным двигательным действиям предполагает следующую организационную структуру: проблемная ситуация $\rightarrow$ постановка проблемной задачи $\rightarrow$ проектирование (конструирование) модели ее решения $\rightarrow$ практическая реализачия проблемной задачи. Логика построения этапов в данной структуре выражает направленность творческих усилий студента, позволяет раскрыть его познавательный потенциал, развивать рефлексивно-дидактическое мышление, формировать черты творческой деятельности - овладевать процедурами творческой деятельности в контексте решения проблемных дидактических задач:

1. Умения переноса собственного дидактического опыта в новую проблемную учебную ситуацию: творческая деятельность студента проявляется в решении какой-либо новой для него проблемы, при этом используются ранее усвоенные дидактические знания и умения для поиска ее решения.

2. Узнавание в новой проблемной учебной ситуации, ранее пройденной (решенной) дидактической задачи: то есть проблема не задана преподавателем (она не очевидна формулировкой таковой), а самостоятельно «открыта» студентом для себя в другой конкретной учебной ситуации, например, в действиях преподавателя в процессе разучивания учащимися нового двигательного действия.

3. Видение (проективно-аналитическая способность) в уже знакомом объекте (в объеме, необходимом для сознательного и прочного овладе- 
ния) его новые, потенциальные функции: то есть студент, овладевая способами (дидактическим инструментарием) по реализации обучающих задач, умеет видеть в них способность послужить в решении иной обучающей цели, в другой реальной проблемной учебной ситуации.

4. Самостоятельная разработка новой «модели» учебно-профессиональной деятельности, на основе комбинирования из известных способов деятельности.

5. Выделение структурных компонентов в новом объекте: студент, столкнувшись с проблемной учебной ситуацией, вычленяет все элементы этого объекта, уточняет существенное и несущественное в соотношении этих элементов.

6. Определение возможности в оптимизации качества решения проблемной задачи (дидактическое моделирование), на основе системного поиска педагогических средств, детализирующих возможность качественно нового решения задачи или различных продуктивных способов решений данной проблемы. Построение принципиально нового способа решения проблемы (отличного от ранее известного студенту) и его реализация.

На предварительном этапе, в процессе разработки системы проблемных задач (заданий), обеспечивающих создание проблемной ситуации, мы исходили из содержания преподаваемой дисциплины, выделяя основные «единицы» учебного материала подлежащих к освоению студентами - соответствующих знаний и практических способов действий, в контексте профессионально-педагогической деятельности выпускников, анализа различных ситуаций реального дидактического процесса. Устанавливается порядок расположения проблемных практико-ориентированных задач/заданий в системе программного курса учебной дисциплины. В содержании задач/заданий выделяются структурные компоненты - условия задачи, объект, требования и конструкт (типовые проектировочно-технологические схемы для решения задач).

Каждая проблемная задача - обучение гимнастическому упражнению на различных этапах его проектирования и осуществления, требует от студента выполнения комплекса профессионально значимых, целенаправленных, педагогически обоснованных практических действий в их целостной структуре: биомеханических и психолого-педагогических знаний, умений и навыков. При этом процесс обучения гимнастическим упражнениям рассматривается как управляемый дидактический процесс (включающий основные составные элементы управляемого обучения), в котором условием формирования дидактических операциональных умений является ориентировочная основа действий (ООД).
Важное место в структуре разрабатываемой системы проблемных заданий отводится формулировке проблемных вопросов, при составлении которых преподавателю следует соблюсти ряд определенных условий, которые специфичны для проблемного обучения:

1. В поставленном вопросе прослеживается логическая связь с ранее усвоенными студентом понятиями (терминами) и представлениями, а также с теми, которые непосредственно подлежат усвоению в данной конкретной дидактической ситуации.

2. Поставленный вопрос содержит в себе познавательную трудность методико-технологического характера, при этом «очерчены» примерные границы известного и неизвестного.

3. Поставленный вопрос вызывает у студента чувство неудовлетворенности, что обусловлено недостаточным на данный момент личным «багажом» знаний, умений и навыков при сопоставлении между новой проблемной задачей и предшествующим опытом в решении проблемных заданий.

Исходя из специфики педагогической деятельности учителя физической культуры, мы предлагаем студентам такие практико-ориентированные задания, которые доступны для решения и, в тоже время, составлены так, чтобы предоставить возможность их решения на разном качественном уровне готовности (репродуктивном, продуктивно-технологическом, творческом) к профессионально-педагогической деятельности, с последующим оцениванием проективно-конструктивных дидактических умений и навыков, рефлексивных умений будущего педагога. В частности, в нашем опыте работы на практических занятиях, где в определенной очередности студенты выступают роли учителя физической культуры, а однокурсники включены в процесс обучения в качестве учащихся, на основе специально разработанных критериев оцениваются:

- знания будущего учителя основ биомеханики разучиваемых гимнастических упражнений (их кинематической структуры: пространственные, временные и пространственно-временные характеристики);

- владение методикой обучения: отбор и использование в решении задач обучения гимнастическим упражнениям форм, методов и средств обучения;

- умения реализации технологий обучения: воспроизведение разнокачественных дидактических процедур как системы прописанных шагов деятельности с заранее заданными характеристиками для решения конкретных обучающих задач по этапам процесса обучения двигательному действию;

- обнаружение и идентификация допускаемых двигательных ошибок и их исправление в процессе 


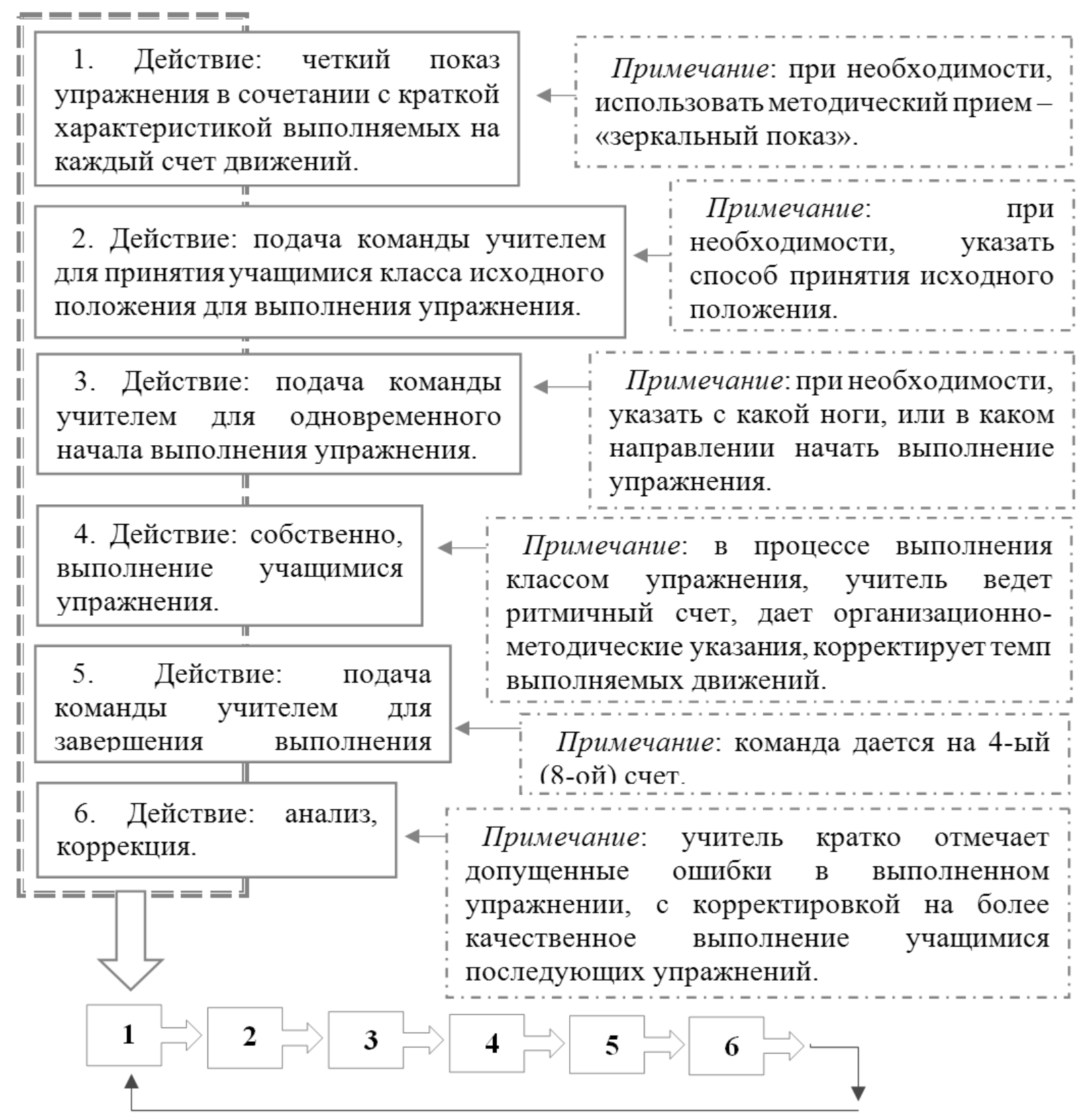

Рис. 1. Модель «обучающего алгоритма» для всех основных способов проведения общеразвивающих гимнастических упражнений.

обучения.

Кроме того, в качестве одного из критериев (обучаемость; время выполнения контрольного задания; интенсивность творческой деятельности; сформированные творческие умения) оценки творческих умений студентов, в рамках конкретного проблемного задания, служит показатель оригинальности разработанного проекта учебного процесса (теоретическая модель) по обучению гимнастическому упражнению, который позволяет преподавателю (как эксперту) выявлять на «теоретическом уровне» качество методических знаний обучаемого в организации учебного процесса, его конструктивно- технологические умения: определять цель и частные задачи, планировать состав, последовательность применения и количество повторов подводящих упражнений для их решения; использование дидактических методов и форм организации учебной деятельности учащихся по этапам обучения.

Для решения проблемных заданий различного типа профессионально-практической направленности, студентам предлагаются к использованию: обучающие алгоритмы (варианты репродуктивного и продуктивнотехнологического уровней представлены на рис. 1-2); ориентировочные технологические карты-инструкции 


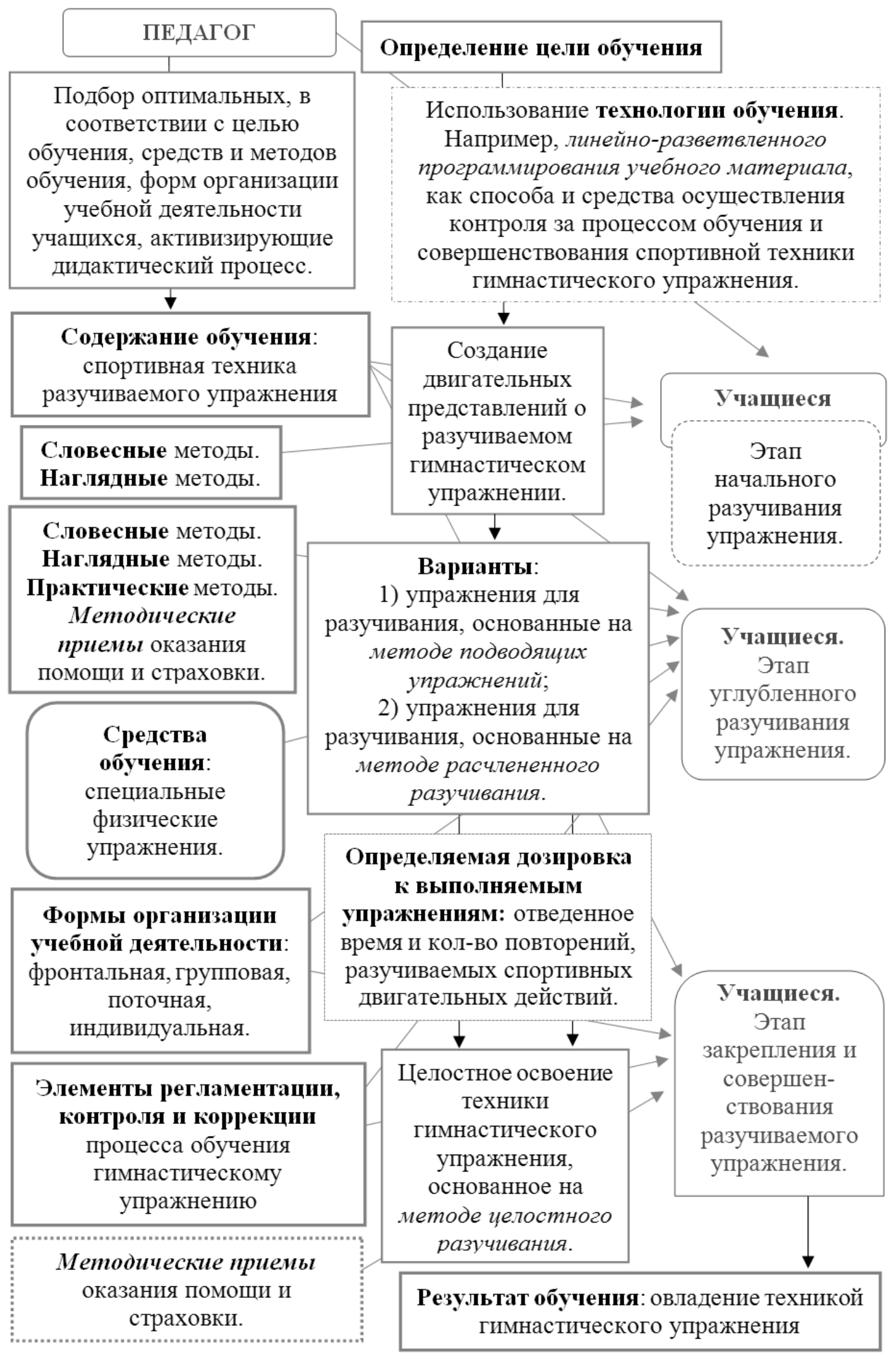

Рис. 2. Универсальная модель проектирования процесса обучения гимнастическим упражнениям. 
Формулировка диагностичной (через результаты \begin{tabular}{|l|l}
1 & $\begin{array}{l}\text { обучения, выраженные в конкретных действиях } \\
\text { учашегося) цели обучения, в соответствии с } \\
\text { mрехэтапной структурой дидактического процесса } \\
\text { обучения двигательному действию. }\end{array}$
\end{tabular}

Определение содержания обучения, в контексте создания четкого представления о технической структуре разучиваемого гимнастического упражнения: выделение опорных (узловых) моментое в технике исполнения, описание его кинематической и динамической структуры - пространственно-временных характеристик. Прогнозирование возможных ошибок при выполнении разучиваемого упражнения, с определением характерных «грубых», «средних» и «мелких» ошибок).

Подбор средств обучения: набор специальных физических упражнений - подводящие и подготовительные упражнения, предлагаемые учащимся для выполнения в определенной дидактической последовательности, по правилу - «от простого к

Обоснованный отбор наиболее приемлемых для решения данной конкретной обучающей задачи дидактических методов, методических приемов оказания помощи/страховки и форм организации учебной деятельности учащихся.

Разработка технологической структуры освоения разучиваемого гимнастического упражнения, построенной на основе четко регламентированного управления дидактическим процессом: прописать шаги деятельности (определить состав, очередность, содержание, составляющих его дидактических операций), обусловливающих достижение обучающей цели, и отвечающих следующим признакам: четкость и определенность в фиксации результата; наличие критериев его достижения; пошаговая и формализованная структура деятельности субъектов обучения.

Построение модели (проекта) дидактического процесса. Оценка результатов на основе анализа теоретического применения разработанного проекта. Коррекция (при необходимости) и реализация оптимизированного варианта конкретного

Рис. 3. Модель технологической карты-инструкции 
(продуктивно-технологический уровень), образовательная ценность которых заключается в том, что в основу их разработки положены операционально-деятельностные, личностно-мотивационные и оценочные компоненты деятельности (рис. 3), которые способствуют формированию умений творческого их применения в разрешении проблемных ситуаций, возникающих в практике обучения.

За итоговый показатель в оценке качества готовности студентов к решению профессионально-ориентированных задач, проводимых, как было отмечено в форме системы последовательно усложняющихся заданий, принимается среднее значение всех выставленных преподавателем оценок в течение семестра (учебного года). При этом, преподаватель использует разработанные для каждого уровня (репродуктивного, продуктивнотехнологического, творческого) владения способами решения задач обучения гимнастическим упражнениям критерии их оценивания.

Обучение студентов решению проблемных задач, в особенности продуктивно-технологического и творческого уровня, является важным фактором в системе формировании предметных компетенций, и требует от преподавателя большого педагогического мастерства для создания атмосферы творческого поиска студентов. Выбирая методы работы на занятиях, следует исходить из назначения каждого метода проблемного обучения и уровня подготовленности студенческой группы. При этом должна преследоваться цель - обеспечение максимальной активности и самостоятельности студента на всех этапах мыслительного процесса. На данной основе происходит качественное изменение уровня проблемности практических занятий.

Большинство профессионально-ориентированных дидактических задач относится к дивергентным задачам (имеющим несколько вариантов правильного решения), по причине того, что обучающие задачи часто представляют собой сложные дидактические ситуации, которые не могут быть решены однозначно. В этом случае для развития профессионального мышления будущего педагога осуществлять творческую и исследовательскую деятельность можно рекомендовать преподавателю не навязывать свою точку зрения, предоставлять студенту право самостоятельно выбрать путь к решению данного задания, в связи с чем он получает возможность соотнести свои возможности и индивидуальный опыт (знания, умения и навыки) с требованиями профессионально-педагогической деятельности учителя физической культуpы.

Необходимо стремиться к тому, чтобы обучающиеся научились предлагать свои варианты решений, первоначально анализировать их, отбирать наиболее адекватные, учиться видеть пути их доказательства. При подобной практике подготовки бакалавров, их учебнопознавательная деятельность будет в большей степени нацелена на формирование профессионально-личностной рефлексии, креативного мышления, раскрытие творческих педагогических способностей.

Таким образом, учебный курс дисциплины «Гимнастика» носит выраженную профессионально-ориентированную направленность, его освоение предполагает выполнение разноуровневых заданий различного типа: ознакомительных (выполняемых с целью закрепления и конкретизации изученного теоретического материала), аналитических (ставящих своей целью освоение новой информации) и творческих (связанных с получением новой информации посредством самостоятельно выбранных подходов к решению задач).

Проблемная организация практических занятий позволяет преподавателю создать такую образовательнотворческую среду для студентов, результатом которой выступают: мыслительная деятельность приобретает осознанность и целостность при изучении и решении проблемных обучающих задач; освоенное содержание учебной дисциплины, переходящее в субъектный дидактический опыт студента, а в целом - прирост его профессионального уровня развития.

Продуктом данной деятельности становится сформированная дидактическая компетентность (определенного уровня) как интегральное качество личности бакалавра, отражающая состояние профессиональной готовности к проектированию и практической реализации учебного процесса по обучению двигательным действиям на уроках физической культуры; приобретение опыта профессиональной поисково-конструктивной деятельности, как системы логически построенных приемов и способов педагогической деятельности.

\section{ЛИТЕРАТУРА}

1. Алешина Н.С., Афонский В.И. Проблема совершенствования подготовки педагогических кадров в системе высшего физкультурного образования // Физическая культура, спорт и здоровье. 2014. № 24. С. 8-9.

2. Анцыперов В.В., Горячева Н.Л. Компетентностный подход в организации и проведении учебных занятий по избранному виду спорта (спортивная акробатика) // Инновации в образовании. 2014. № 2. С. 5-11. 
3. Белобородова М.Е. Обучение студентов рефлексии как инструменту контроля и оценки собственной учебной деятельности // Образование личности. 2019. №2. С. 105-112.

4. Берекбусунова Г., Кулбаев А., Унтаев Х., Турарова Г., Тураров С. Эффективность профессиональной подготовки будущих учителей физической культуры // Теория и практика физической культуры. 2019. № 7. С. 10-12.

5. Демченко М.О. Дидактическое проектирование в профессиональной деятельности педагога // Мир науки, культуры, образования. 2017. № 6 (67). С. 208-210.

6. Зорина 0.В. Профессиональная подготовка учителей физической культуры к инновационной учебной деятельности // Проблемы современного педагогического образования. 2016. № 50-1. С. 91-97.

7. Поливаев А.Г. Состояние и перспективы совершенствования качества подготовки физкультурных кадров в педагогическом вузе // Педагогическое образование и наука. 2014. № 4. С. 125-129.

8. Поливаев А.Г., Черемисов А.В. Качество подготовки физкультурных кадров для общеобразовательной школы в педагогическом вузе: проблемы и перспективы // Омский научный вестник. 2014. № 3 (129). С. 167-170.

9. Самойленко Т.В., Рамашов Н.Р., Малай Л.Ю., Назарова А.М., Барбанова Н.В. К вопросу о проблемах подготовки физкультурных кадров в высших учебных заведениях // Актуальные научные исследования в современном мире. 2017. №1-2 (21). С. 125-128.

10. Селевко Г.К. Современные образовательные технологии. Учебное пособие. М: Народное образование, 1998. 256 с.

11. Современные технологии обучения и воспитания. Книга 2: монография / Ю.В. Дементьева, А.В. Джевага и др. Новосибирск, 2018. 164 с.

12. Сыпко Е.В., Власова В.И., Демченко Н.Ю. Изучение использования самостоятельной работы студентов с элементами проблемного обучения в учебном процессе вуза // European Social Science Journal. 2016. № 11. C. 281-287.

13. Усцелемова Н.А., Усцелемов С.В. Анализ состояния проблемы профессиональной подготовки физкультурных кадров в России // Современные тенденции развития науки и технологий. 2016. № 10-13. С. 138-140.

14. Цыбуленко 0.П. Использование проблемного обучения в образовательном процессе высшего образования как важная составляющая профессиональной подготовки // Образование личности. 2019. № 3-4. С. $42-51$.

( О Омаров Омаркады Магомедзагирович (omar-kadi@yandex.ru), Борлакова Баблина Магомедовна (bablina.borlakova@yandex.ru),

Новикова Наталья Борисовна (omar-kadi@yandex.ru).

Журнал «Современная наука: актуальные проблемы теории и практики»

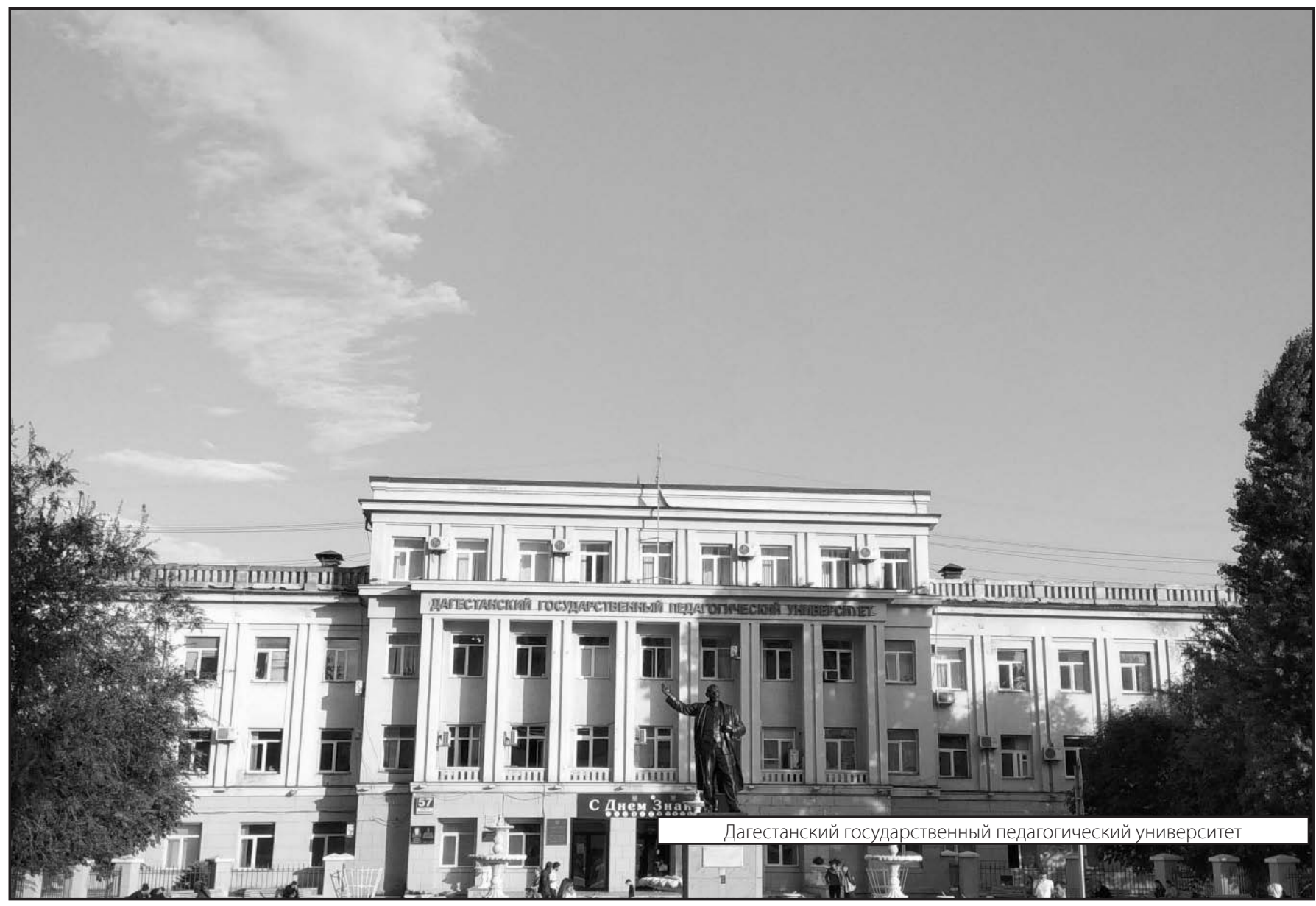

